Research article

\title{
Bioleaching of toxic metals from sewage sludge by co-inoculation of Acidithiobacillus and the biosurfactant-producing yeast Meyerozyma guilliermondii
}

\author{
Franciele Pereira Camargo a, *, Pierre Ferreira do Prado ${ }^{b}$, Paulo Sergio Tonello ${ }^{b}$, \\ André Cordeiro Alves Dos Santos ${ }^{c}$, Iolanda Cristina Silveira Duarte ${ }^{a}$ \\ a Graduate Program of Biotechnology and Environmental Monitoring, Federal University of São Carlos (UFSCar), Rodovia João Leme dos Santos, km 110, \\ Itinga, Sorocaba, SP, Brazil \\ ${ }^{\mathrm{b}}$ Graduate Program of Environmental Sciences, São Paulo State University (UNESP), Avenida Traês de Março 511, Alto da Boa Vista, 18087-180, Sorocaba, \\ São Paulo, Brazil \\ ${ }^{\mathrm{c}}$ Department of Biology, Federal University of São Carlos, Rodovia João Leme dos Santos, km 110, Itinga, Sorocaba, SP, Brazil
}

\section{A R T I C L E I N F O}

\section{Article history:}

Received 8 May 2017

Received in revised form

10 January 2018

Accepted 15 January 2018

Available online 4 February 2018

\section{Keywords:}

Sewage treatment

Glycolipid

Heavy metal

\begin{abstract}
A B S T R A C T
The aim of this research is to evaluate the influence of co-inoculation of Acidithiobacillus bacteria and the biosurfactant-producing yeast Meyerozyma guilliermondii in bioleaching processes. The tests were carried out using sewage sludge from UASB reactors co-inoculated with cultures of Acidithiobacillus and M. guilliermondii to promote the solubilization of $\mathrm{Cd}, \mathrm{Cr}, \mathrm{Cu}, \mathrm{Ni}, \mathrm{Pb}$ and $\mathrm{Zn}$ which were determined by Inductively Coupled Plasma - Optical Emission Spectrometry (ICP- OES). After 10 days of incubation, $76.5 \%$ of $\mathrm{Zn}, 59.8 \%$ of $\mathrm{Ni}, 22.0 \%$ of $\mathrm{Cu}, 9.8 \%$ of $\mathrm{Cd}, 9.8 \% \mathrm{Cr}$ and $7.1 \%$ of $\mathrm{Pb}$ were solubilized. It was observed that the presence of yeast accelerated the time required for $\mathrm{Cd}$ solubilization from 240 to $96 \mathrm{~h}$ and there was a $20.1 \%$ reduction in nitrogen concentration and $7.6 \%$ for phosphorus in this assay. After the bioleaching and co-inoculation assays, the product obtained reached the maximum permissible concentrations for soil disposal for all the analyzed metals in the State of São Paulo, United States and also European Community standards.
\end{abstract}

() 2018 Elsevier Ltd. All rights reserved.

\section{Introduction}

One of the consequences of an increase in the population and economic activity is the exponential growth in waste generation, such as sewage sludge (Azizi et al., 2013). Sewage treatment systems aim at minimizing the environmental impacts caused by improper disposal (Du et al., 2015; Zhang et al., 2014). Therefore, sewage sludge treatment can also generate secondary waste, such as sewage sludge, which can contaminate soil and water (Mao et al., 2015).

Because of the nutrient composition of sewage sludge, it can be used as a fertilizer and it is one of the alternatives recommended for its destination, but the presence of pathogenic organisms, organic and also inorganic pollutants, especially toxic metals, can restrict

\footnotetext{
* Corresponding author. Universidade Federal de São Carlos, Rodovia João Leme dos Santos, Km 101, Itinga, 18052780, Sorocaba, São Paulo, Brazil.

E-mail address: camargofp@usp.br (F.P. Camargo).
}

this allocation. The metals cadmium $(\mathrm{Cd})$, copper $(\mathrm{Cu})$, chrome $(\mathrm{Cr})$, nickel $(\mathrm{Ni})$, zinc $(\mathrm{Zn})$, lead $(\mathrm{Pb})$ and metalloid arsenic $(\mathrm{As})$ are the most common inorganic pollutants that can be found in this kind of material (Pathak et al., 2009).

Most of the cationic contaminants, such as toxic metals, are found in soil, sediment and sludge adsorbed in the organic fraction or in particulate material. In fact, these elements are mostly $\mathrm{pH}$ dependent and are more soluble in acid conditions and more insoluble and adsorbed/complexed with other compounds in alkaline conditions. This occurs because the ligation sites are also pH-dependent (McLean and Bledsoe, 1992) and at acidic pHs, many of the functional groups that were observed in the organic matter of the sewage sludge become protonated, releasing metals and, consequently, solubilizing them. Therefore, most of the techniques to remove toxic metals from sewage sludge are based on this assumption (Camargo et al., 2016).

An emerging technique to solubilize toxic metals from sewage sludge is known as bioleaching. According to Pathak et al. (2009), in short, bioleaching is a process based on the principle that the 
metabolism of bacteria from Acidithiobacillus genus can naturally acidify the medium. Although there is a large body of research on metal bioleaching from soils (Chen and Lin, 2001; Kumar and Nagendran, 2007; Mulligan et al., 2001; Naresh Kumar and Nagendran, 2009), there are only a few contributions in the field of sewage sludge treatment (Fang and Zhou, 2007; Wen et al., 2013; Zhou et al., 2013a).

Previous studies have clearly shown that the bioleaching process using species of Acidithiobacillus genus shows better results when the experiments were conducted using the widely known acidophilic species, A. ferrooxidans and A. thiooxidans, in coinoculation (Pathak et al., 2009).

Recent research, Zhou et al. (2013a, 2013b), have shown that adding the yeast Galactomyces sp. Z3 in sludge could increase the bioleaching process. This is because heterotrophic microorganisms can also consume some organic acids that can inhibit or retard the Acidithiobacillus growth (Karwowska et al., 2014; Ngom et al., 2014) as they produce a substance known as biosurfactant, which can improve the metal solubilization (Banat et al., 2010). These studies have greatly contributed to our understanding of how much the coinoculation of biosurfactant producing yeasts with Acidithiobacillus bacteria can affect the metal solubilization and degradation of inhibitory substances in sludge. The authors showed that coinoculation of Galactomyces sp. Z3 and Acidithiobacillus strains reduced the period required for sludge bioleaching by 4.5 days compared to Acidithiobacillus alone in sewage sludge (Zhou et al., 2013a) and also in pig slurry (Zhou et al., 2013b), removing about $94 \%$ of $\mathrm{Zn}$ and $85 \%$ of $\mathrm{Cu}$ in the last substrate of the co-inoculation assays. On the other hand, in the control assay (without Acidithiobacillus bacteria or Galactomyces sp. inocula), there was approximately $51 \%$ of $\mathrm{Zn}$ solubilization. Cu solubilization in this assay was hardly observed and the authors attributed this result to the decline in $\mathrm{pH}$ from 5.3 to 4.1 , meaning that the $\mathrm{pH}$ required for $\mathrm{Cu}$ solubilization was lower than $\mathrm{Zn}$ solubilization.

Despite the acceptance of the contribution of yeasts to the bioleaching process, there are few studies addressing the use of wild strains as data already published focus on standardized strains, such as Galactomyces sp. Z3 (Zhou et al., 2013a, 2013b) and Brettanomyces B65 (Fang and Zhou, 2007).

Could the co-inoculation of a wild strain of an acidophilic biosurfactant-producing yeast with Acidithiobacillus bacteria increase the bioleaching process of the metals $\mathrm{Cd}, \mathrm{Cr}, \mathrm{Cu}, \mathrm{Ni}, \mathrm{Pb}$ and $\mathrm{Zn}$ in sewage sludge? Is it possible to use the final product as a source of nitrogen and phosphorus, i.e., a fertilizer for farmland? The main aim of this paper is to investigate and answer these questions by coinoculating a $M$. guilliermondii wild strain with the Acidithiobacillus (A. ferrooxidans and A. thiooxidans) bacteria in bioleaching processes in anaerobic sewage sludge.

\section{Methods}

\subsection{Sludge sample and its characteristics}

Anaerobic sludge was collected from a municipal wastewater treatment plant (WWTP) in Porto Feliz (São Paulo, Brazil), of the biological treatment step of the wastewater, directly from the upflow anaerobic sludge blanket reactor (UASB), and stored at $4{ }^{\circ} \mathrm{C}$ until used. The 1060 method from the Standard Methods for the Examination of Water and Wastewater was adopted to collect and store the sludge (APHA/AWWA/WEF, 2012).

The $\mathrm{pH}$ was measured immediately by directly immersing a previously sterilized electrode (formaldehyde $5 \%$ ), while total solid (TS) content and volatile total solids (VTS) were measured according to the $2540 \mathrm{~B}$ and $2540 \mathrm{E}$ methods, respectively (APHA/ AWWA/WEF, 2012). The total nitrogen (N) and total phosphorus
(P) were analyzed according to the $4500-\mathrm{N}_{\text {org }}$ and $4500 \mathrm{~B}$ methods, respectively (APHA/AWWA/WEF, 2012). Sulfate $\left(\mathrm{SO}_{4}^{-2}\right)$ was determined using the SulfaVer ${ }^{\circledR}$ kit (Permachem Reagents ${ }^{\circledR}$, Hach $^{\circledR}$ ) following the manufacturer's recommendations based on the Standard Methods for the Examination of Water and Wastewater (APHA/AWWA/WEF, 2012). For the qualitative identification of the functional groups, Fourier Transform Infrared Spectroscopy (FT-IR) was used in the range of $4000-400 \mathrm{~cm}^{-1}$ and 32 scans using $1 \%$ potassium bromide tablets $(\mathrm{KBr})$. The crude sludge was dried in an oven at $40^{\circ} \mathrm{C}$ until a constant weight was reached.

The microbial behavior of bacteria of the genus Acidithiobacillus (A. thiooxidans and A. ferrooxidans) and Thiobacillus (T. thioparus) was evaluated according to the CETESB L5.217 standard (CETESB, 2004) using the most probable number (MPN) technique.

The content of toxic metals was analyzed in the solid phase according to the 3050B method (USEPA, 1996) and in the liquid phase according to the 3030E method (APHA/AWWA/WEF, 2012) after sludge centrifugation ( $\left.10.000 \mathrm{rpm}, 4{ }^{\circ} \mathrm{C}, 10 \mathrm{~min}\right)$. The metals $\mathrm{Cd}, \mathrm{Cr}, \mathrm{Cu}, \mathrm{Ni}$ and $\mathrm{Zn}$ were quantified by Inductively Coupled Plasma Optical Emission Spectrometry (ICP-OES). Table 1 shows the selected physicochemical properties of the sludge.

\subsection{Microorganisms and inoculum preparation}

The species A. ferrooxidans (ATCC 23270) and A. thiooxidans (ATCC 19377), provided by the Hydrometallurgy Laboratory from São Paulo State University (UNESP) "Julio de Mesquita Filho", campus Araraquara, were cultivated in modified $9 \mathrm{~K}$ liquid medium $\left(\left(\mathrm{NH}_{4}\right) \cdot 2 \mathrm{SO}_{4} 3.0 \mathrm{~g} ; \mathrm{KCl} 0.1 \mathrm{~g} ; \mathrm{K}_{2} \mathrm{HPO}_{4} 0.5 \mathrm{~g} ; \mathrm{MgSO}_{4} \cdot 7 \mathrm{H}_{2} \mathrm{O} 0.5 \mathrm{~g} ; \mathrm{H}_{2} \mathrm{O}\right.$ $1000 \mathrm{~mL}, \mathrm{pH} 2.8)$ and modified $\mathrm{T} \& \mathrm{~K}$ liquid medium $\left(\left(\mathrm{NH}_{4}\right)_{2} \mathrm{SO}_{4}\right.$ $2.5 \mathrm{~g} ; \mathrm{KH}_{2} \mathrm{PO}_{4} 0.45 \mathrm{~g} ; \mathrm{MgSO}_{4} \cdot 7 \mathrm{H}_{2} \mathrm{O} 2.5 \mathrm{~g}, \mathrm{H}_{2} \mathrm{O} 1000 \mathrm{~mL}, \mathrm{pH} 1.8$ ), respectively (Fang et al., 2011). Both media were autoclaved at $121^{\circ} \mathrm{C}$ for $20 \mathrm{~min}$ and the $9 \mathrm{~K}$ medium was spiked with $44.2 \mathrm{~g} / \mathrm{L}$ of $0.22 \mu \mathrm{m}$ membrane-filtered $\mathrm{FeSO}_{4} \cdot 7 \mathrm{H}_{2} \mathrm{O}$ and the $\mathrm{T} \& \mathrm{~K}$ medium was spiked with $10.0 \mathrm{~g} / \mathrm{L}$ of elemental sulfur $\left(\mathrm{S}^{0}\right)$ as energy sources. The $\mathrm{pH}$ was adjusted with $\mathrm{H}_{2} \mathrm{SO}_{4} 1 \mathrm{M}$ and $\mathrm{NaOH} 1 \mathrm{M}$. The inoculum was prepared by growing the two-bacterial species in $250 \mathrm{~mL}$ erlenmeyer flasks each containing $100 \mathrm{~mL}$ of the $9 \mathrm{~K}$ or T\&K medium at $150 \mathrm{rpm}$ and $30^{\circ} \mathrm{C}$. The A. ferrooxidans and A. thiooxidans cell numbers were about $10^{8}$ cells $/ \mathrm{mL}$ at the end of their exponential phase of growth (about $48 \mathrm{~h}$ or 15 days after inoculation), separately (Zhou et al., 2013a).

The Meyerozyma guilliermondii yeast was originally isolated from soil contaminated by diesel and it is available at the Laboratory of Environmental Microbiology collection at the Federal University of São Carlos, Sorocaba campus (São Paulo, Brazil). It was identified using the ribosomal RNA gene sequence (Genebank access number KX455848, http://www.ncbi.nlm.nih.gov). The strain can grow in acid conditions ( $\mathrm{pH}$ around 2.0 ) and produce biosurfactant/glycolipids similar to sophorolipids (unpublished data).

As previously described in Zhou et al. (2013a) for Galactomyces sp. Z3, the M. guilliermondii strain was cultivated for in Czapek medium $\left(\mathrm{NaNO}_{3}, 2.0 \mathrm{~g} ; \mathrm{K}_{2} \mathrm{HPO}_{4}, 1.0 \mathrm{~g} ; \mathrm{MgSO}_{4} \cdot 7 \mathrm{H}_{2} \mathrm{O}, 0.5 \mathrm{~g} ; \mathrm{KCl}\right.$, $0.5 \mathrm{~g} ; \mathrm{FeSO}_{4} \cdot 7 \mathrm{H} 2 \mathrm{O}, 0.01 \mathrm{~g}$; sucrose $30.0 \mathrm{~g}$; distilled water $1 \mathrm{~L} ; \mathrm{pH}$ $4.0 \pm 0.2$ ) before use. The yeast inoculum was obtained by growing the cells in $500 \mathrm{~mL}$ Erlenmeyer flasks, containing $250 \mathrm{~mL}$ of the described Czapek medium on a gyratory shaker at $150 \mathrm{rpm}$ and $30^{\circ} \mathrm{C}$, and the M. guilliermondii cell numbers were about $10^{7}$ cells/ $\mathrm{mL}$ at the end of their exponential phase of growth (about $48 \mathrm{~h}$ after inoculation).

\subsection{Effect of M. guilliermondii on the sludge bioleaching}

Sewage sludge bioleaching experiments were carried out according to the modified method described in Zhou et al. (2013b), 
Table 1

Physicochemical characteristics of anaerobic sewage sludge before and after the bioleaching assays.

\begin{tabular}{|c|c|c|c|c|}
\hline \multirow[t]{2}{*}{ Parameters } & \multirow[t]{2}{*}{ Initial concentration } & \multicolumn{3}{|l|}{ Assays } \\
\hline & & Control & Bioleaching & Co-inoculation \\
\hline $\mathrm{pH}$ & $7.4 \pm 0.0$ & $6.1 \pm 0.1$ & $2.1 \pm 0.1$ & $2.2 \pm 0.0$ \\
\hline TS, \% & 10.4 & 8.9 & 9.2 & 9.9 \\
\hline TVS, \% TS & 59.5 & 36.1 & 36.4 & 32.9 \\
\hline $\mathrm{SO}_{4}^{2}, \% \mathrm{TS}$ & 3.9 & 9.5 & 12.5 & 7.1 \\
\hline Total N, \% TS & 0.7 & 0.6 & 0.6 & 0.6 \\
\hline Total P, \% TS & 0.2 & 0.3 & 0.3 & 0.2 \\
\hline $4 \mathrm{Cd}, \mathrm{mg} / \mathrm{kg}$ & $520.7 \pm 0.0$ & $18.4 \pm 0.0$ & $17.21 \pm 0.5$ & $18.2 \pm 0.0$ \\
\hline $6 \mathrm{Cr}, \mathrm{mg} / \mathrm{kg}$ & $7619.9 \pm 0.0$ & $572.8 \pm 0.1$ & $542.56 \pm 0.3$ & $552.0 \pm 0.1$ \\
\hline $8 \mathrm{Cu}, \mathrm{mg} / \mathrm{kg}$ & $92201.0 \pm 1.8$ & $2128.5 \pm 0.0$ & $1378.6 \pm 0.3$ & $1714.2 \pm 0.2$ \\
\hline $10 \mathrm{Ni}, \mathrm{mg} / \mathrm{kg}$ & $11356.0 \pm 6.3$ & $345.2 \pm 0.1$ & $166.9 \pm 4.9$ & $140.3 \pm 0.0$ \\
\hline $12 \mathrm{~Pb}, \mathrm{mg} / \mathrm{kg}$ & $1629.2 \pm 0.0$ & $442.0 \pm 0.1$ & $414.6 \pm 0.0$ & $421.6 \pm 0.1$ \\
\hline $13 \mathrm{Zn}, \mathrm{mg} / \mathrm{kg}$ & $148216.8 \pm 0.1$ & $7955.1 \pm 0.0$ & $2438.6 \pm 3.8$ & $2008.4 \pm 0.0$ \\
\hline
\end{tabular}

where $500 \mathrm{~mL}$ erlenmeyer flasks containing $222.5 \mathrm{~mL}$ autoclaved sewage sludge $\left(121^{\circ} \mathrm{C}\right.$ for $\left.20 \mathrm{~min}\right)$ and $12.5 \mathrm{~mL}$ A. ferrooxidans + A. thiooxidans as inoculum. $2.0 \mathrm{~g} / \mathrm{L}$ of $\mathrm{Fe}^{2+}$ (as $\left.\mathrm{FeSO}_{4} \cdot 7 \mathrm{H}_{2} \mathrm{O}, 10.0 \mathrm{~g} / \mathrm{L}\right), 2.0 \mathrm{~g} / \mathrm{L}$ of elemental sulfur $\left(\mathrm{S}^{0}\right)$, and $15 \mathrm{~mL}$ of $M$. guilliermondii (as described in item 2.2) were added to the flasks mentioned above (hereafter referred to as the co-inoculation system). Control flasks contained only the energy substances $(2.0 \mathrm{~g} / \mathrm{L}$ of $\mathrm{Fe}^{2+}$ and $2.0 \mathrm{~g} / \mathrm{L}$ of $\mathrm{S}^{0}$ ) and all flasks were filled with ultrapure water $(03.1 \mathrm{M} \Omega \mathrm{cm})$ up to $250 \mathrm{~mL}$, when necessary. All flasks were incubated at $30^{\circ} \mathrm{C}$ and $150 \mathrm{rpm}$ during the incubation period of 10 days, and $10 \mathrm{~mL}$ of sewage sludge samples were withdrawn from the flasks every $24 \mathrm{~h}$ to analyse the $\mathrm{pH}$ and metal content.

The samples were centrifuged $\left(10.000 \mathrm{rpm}, 4{ }^{\circ} \mathrm{C}, 10 \mathrm{~min}\right)$ and then the liquid phase was acidified with $\mathrm{HNO}_{3}(\mathrm{pH}<2.0)$ and stored at $4{ }^{\circ} \mathrm{C}$ until used. The metals and the physicochemical analysis were carried out as described in item 2.1. All the treatments were carried out in duplicate and data presented were the mean and standard deviations of two independent samples.

\subsection{Data analysis}

The metal solubilization (\%) in the solid phase of the sewage sludge at the end of each test was calculated by the ratio between the concentration of metal solubilized and the total concentration of the metal in the sludge.

The assay results were compared using the parametric analysis of variance (ANOVA), evaluating their relevance using Graph Pad Instat software with a $95 \%$ confidence interval.

\subsection{Theoretical study of the solubility of metals at different $\mathrm{pH}$ values}

In order to evaluate if toxic metals were mostly in soluble species or precipitated forms, the software Visual MINTEQ 3.1 (Gustafsson, 2016) was used as an alternative chemical equilibrium model. The values of total metals $(\mathrm{Cd}, \mathrm{Cr}, \mathrm{Cu}, \mathrm{Ni}$ and $\mathrm{Zn})$, total phosphorus and nitrogen and sulfate obtained in the initial characterization of sewage sludge were used (Table 1), such as the fixed values of $\mathrm{S}^{0}(2.0 \mathrm{~g} / \mathrm{L}) \mathrm{Fe}^{2+}(2.0 \mathrm{~g} / \mathrm{L})$ and temperature $\left(30^{\circ} \mathrm{C}\right)$.

\section{Results and discussion}

\subsection{Physicochemical parameters during the bioleaching process}

Pathak et al. (2009) state that nitrogen and phosphorus can respectively reach concentrations between $1.5-6.0 \%$ and $0.8-11.0 \%$ of TS and in the present study, values of $0.7 \%$ of TS for nitrogen and $0.2 \%$ for phosphorus were found.
MPN assays to determine endogenous Acidithiobacillus and Thiobacillus from sewage sludge indicated that A. ferrooxidans, A. thiooxidans and $T$. thioparus were already present in the material analyzed. An endogenous bacterium of sewage sludge (T. thioparus) is related to the bioleaching process besides acidophilic bacteria (Chen and Lin, 2001) and is even one of the main bacteria responsible for natural acidification of sewage sludge (Blais et al., 1993).

The sewage sludge was submitted to FT-IR analysis to determine the functional groups. The results are presented in the frequency of $4.000-400 \mathrm{~cm}^{-1}$ and the analyses of the functional groups corresponding to the bands were performed according to Silverstein and Webster (1981) (Fig. 1). A broad band of approximately $3.500 \mathrm{~cm}^{-1}$, characteristics for stretching hydroxyl $(\mathrm{OH})$ groups of carboxylic acid, water, alcohols and/or phenols and amides and amines (N-H) were observed. It is known that hydroxylic and carboxylic groups can adsorb the metals, forming chelates that are considerably stable (Pinheiro, 2007).

In the portion between 2.960 and $2.850 \mathrm{~cm}^{-1}$, there are aliphatic hydrocarbon groups $\left(\mathrm{CH}_{3}\right.$ and $\left.\mathrm{CH}_{2}\right)$. These groups can be found in hydrocarbons and cellulose, for example, which are very common in sewage sludge. Bands around $1.000 \mathrm{~cm}^{-1}$ may be related to silicates and/or to sulfoxide groups $(\mathrm{S}=\mathrm{O})$. Identifying functional groups becomes less representative after the region known as

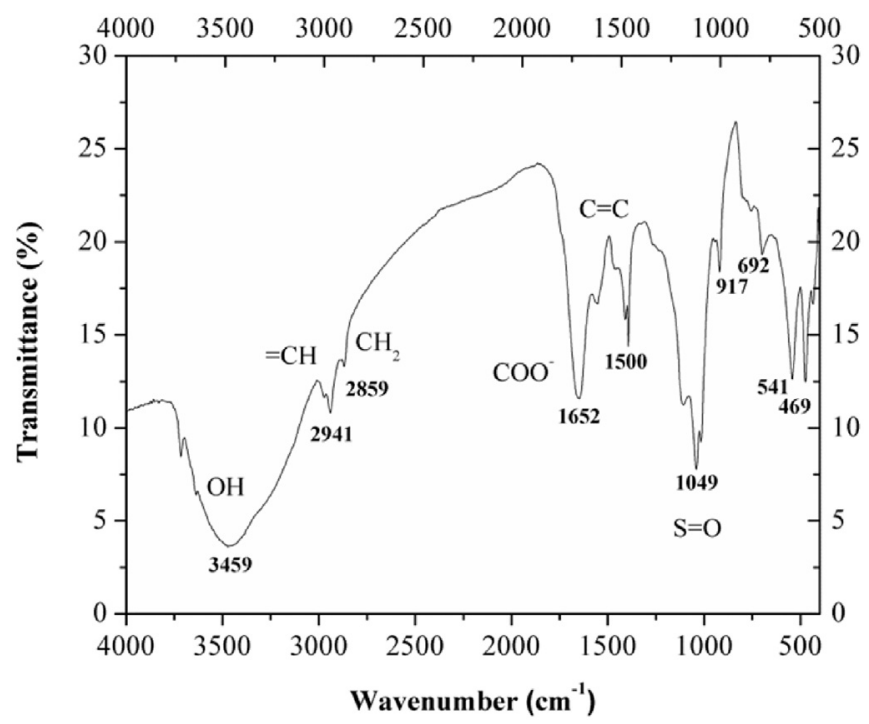

Fig. 1. Fourier Transform Infrared Spectroscopy (FT-IR) of anaerobic sewage sludge. Spectrogram generated by the OriginPro8 program. 
"fingerprint" $\left(<900 \mathrm{~cm}^{-1}\right)$, however bands in this region may suggest the presence of cycloaliphatic structures, aromatic structures, halogenated derivatives and also compounds containing phosphorus (Pedroza et al., 2011).

The characteristic bands of $\mathrm{C}-\mathrm{OH}$ groups in phenols at $1.270 \mathrm{~cm}^{-1}$ were not observed, and nor were the characteristic bands of $\mathrm{C}=\mathrm{O}$ stretches of the $\mathrm{COOH}$ group, aldehydes and ketones at $1.710 \mathrm{~cm}^{-1}$, which may suggest both their non-existence as the link between these groups and the metals present in the sewage sludge. In addition, the band at approximately $1.600 \mathrm{~cm}^{-1}$ may suggest the presence of $\mathrm{C}=\mathrm{C}$ of aromatics, especially due to their intensity, but the presence of an asymmetric stretching band of $\mathrm{COO}$ at approximately $1.650 \mathrm{~cm}^{-1}$ may also suggest the formation of metal complexes (Polak et al., 2005).

\subsection{Concentrations of metals during the bioleaching process}

The metal characterization of sewage sludge was again performed after the incubation period of the reactors (10 days) (Table 1). The $\mathrm{pH}$ was quite stable in the control reactor remaining around 6.0 (Fig. 2-A). Changes in the $\mathrm{pH}$ throughout the incubation period can be possible attributed to iron hydrolysis and chemical/ aerobic decomposition of organic matter (Zhou et al., 2013b).

The $\mathrm{pH}$ of the medium is an important parameter because it can directly influence sorption/desorption reactions, precipitation/ dissolution, complex formation and oxidation-reduction reactions (McLean and Bledsoe, 1992).

Gradual acidification of bioleaching and co-inoculation assays can be attributed to the presence of Acidithiobacillus inoculum (Chen and Lin, 2001; Pathak et al., 2009). Both assays reached a final $\mathrm{pH}$ close to 2.0 after the incubation period and this value is typical of the final stage of the bioleaching process (Zheng and Zhou, 2011).

The concentration of all evaluated metals gradually increased over the incubation period in the bioleaching and co-inoculation assays, but to a lesser extent in the co-inoculation assay, while the $\mathrm{pH}$ decreased similarly.

The increase in the concentration of metals in the solution occurs due to the acidification of the medium as the cationic elements in interaction with the solid phase of the sludge are adsorbed or complexed in the particulate or organic matter of the sludge, while the $\mathrm{pH}$ is close to neutrality. Although adsorption can be $\mathrm{pH}$ dependent, acidification of the medium decreases the negative sites present in the organic matter, such as carbonates, clay minerals, iron, manganese oxides, among others, reducing the possibilities of adsorption sites for cationic elements while increasing competition between these ions and also among the other cationic ions present in the solution, such as $\mathrm{Al}^{3+}$ and $\mathrm{H}^{+}$(McLean and Bledsoe, 1992).

As expected, the concentration of metals in the solid phase of the sludge tends to decrease as the concentration in the liquid phase tends to increase. All the elements presented a higher percentage of solubilization in the bioleaching assays than in the control assays, due to the acidification of the latter through the activity of acidophilic bacteria of the genus Acidithiobacillus (Fig. 2).

According to the data obtained and shown in graphs in Fig. 2-B$\mathrm{F}$, all metals evaluated reached their maximum concentration in the liquid phase at the end of the treatment, coinciding with the more acidic $\mathrm{pH}$ reached by the reactors, of approximately 2.0 exceptions: $\mathrm{Cd}$, which reached the maximum concentration at $216 \mathrm{~h}$ in the bioleaching assay and $96 \mathrm{~h}$ in co-inoculation assay, and $\mathrm{Cu}$, which reached its maximum concentration in the co-inoculation assay at $168 \mathrm{~h}$.

In the co-inoculation assay, $\mathrm{Cd}$ presented a final result lower than the final result of the bioleaching assay (Fig. 2-D), however this assay reached its highest solubilization of metals in $96 \mathrm{~h}$.
Furthermore, at this point, the solubilization of this metal was higher than the final result of the bioleaching assay. Possibly the presence of yeast favored the solubilization of this element (Zhou et al., 2013b).

All treatments presented a statistically significant difference in relation to the control assay ( $\mathrm{p}<.001)$, except for $\mathrm{Cr}$ in the coinoculation assay $(\mathrm{p}>.05)$. There was also a significant statistical difference between bioleaching and co-inoculation assays, except for $\mathrm{Cu}(\mathrm{p}>.05)$ and $\mathrm{Ni}(\mathrm{p}>.05)$.

The metal solubilization $\mathrm{Cu}$ (37.4\%), $\mathrm{Ni}(53.1 \%)$ and $\mathrm{Zn} \mathrm{(70.3 \% )} \mathrm{in}$ the co-inoculation assay presented the best results compared to the control assay, where the solubilization percentage was only 3.4; 5.18 and 3.2\%, respectively, while for $\mathrm{Cd}(17.9 \%), \mathrm{Cr}(12.6 \%)$ and $\mathrm{Pb}$ (8.1\%), there was also greater solubilization in relation to the control assay, where $12.7 ; 10.0$ and $3.8 \%$ solubilization was obtained, respectively.

$\mathrm{Ni}$ and $\mathrm{Zn}$ presented a solubilization percentage of 59.8 and 76.5\% for the co-inoculation assay and 53.1 and $70.3 \%$ for the bioleaching assay, respectively. The co-inoculation presented results of solubilization of metals higher than the control assay. These data are not in agreement with the results obtained for analyzing the metals in the liquid phase at the end of the tests. According to these data, it was expected that at the end of the incubation period, the bioleaching assay would be more efficient for all the metals studied, without exceptions, because at the end of the incubation period, there was more solubilization of these elements in the coinoculation assay (Fig. 3).

The solubilization results obtained are lower than those presented in other research regarding some metals (Wen et al. (2013) for $\mathrm{Zn}, \mathrm{Cu}$ and $\mathrm{Pb}(88,79$ and $50 \%$, respectively)). However, it is important to note that the incubation period used by these authors was longer (12 days) and this can increase the chances of nutrient loss (Pathak et al., 2009). Furthermore, the results obtained from the control experiment (sterilized sewage sludge + energy source) are also better when compared to this study ( $80.2 \%$ for $\mathrm{Zn}, 21.8 \%$ for $\mathrm{Cu}$ and $10.9 \%$ for $\mathrm{Pb}$ ). That is, in spite of their final solubilization values being higher, these authors obtained only $7.8 \%$ more solubilization for $\mathrm{Zn}$ than in their control, while in the conditions evaluated in the present study, there is $67 \%$ more solubilization of $\mathrm{Zn}$ in the bioleaching assay in relation to the control assay.

When there are no significant differences between the control and bioleaching assays, the leaching of metals is attributed mainly to the chemical leaching and the bioleaching becomes secondary (Wen et al., 2013). Solubilization varies according to the evaluated metal as each element has its own adsorption/complexation characteristics in specific pH ranges (McLean and Bledsoe, 1992).

Similarly, Wong et al. (2004) also obtained final solubilization values higher than those obtained in the present study. They were $99 \%$ for $\mathrm{Zn}, 65 \%$ for $\mathrm{Cr}, 74 \%$ for $\mathrm{Cu}, 58 \%$ for $\mathrm{Pb}$ and $84 \%$ for $\mathrm{Ni}$, while in its control assay (sludge + energy source) obtained $94 \%, 12 \%, 21 \%$, $32 \%$ and $38 \%$ for these same metals, respectively. Thus, it can be stated that the solubilization was only $5 \%$ higher for $\mathrm{Zn}, 62 \%$ for $\mathrm{Cr}$, $53 \%$ for $\mathrm{Cu}, 26 \%$ for $\mathrm{Pb}$ and $46 \%$ for $\mathrm{Ni}$. $\mathrm{Zn}$ and $\mathrm{Ni}$ presented higher values of solubilization in the present study and were $67 \%$ and $47.9 \%$, respectively. It is important to note that the incubation time used by Wong et al. (2004) was also higher (16 days).

Based on the data obtained and shown in Fig. 2, it can be seen that the co-inoculation assay was less efficient compared to the bioleaching assay for all metals, except for $\mathrm{Cd}$, as discussed above. It was expected that, as described by Zhou et al. (2013b) when adding yeasts of the genus Galactomyces to the reactors, the addition of M. guilliermondii could also promote greater solubilization of the other metals and in a shorter incubation time. However, this was not observed for $\mathrm{Cr}, \mathrm{Cu}, \mathrm{Ni}$ and $\mathrm{Zn}$. In Zhou et al. (2013b), the coinoculation of Galactomyces and Acidithiobacillus increased the 

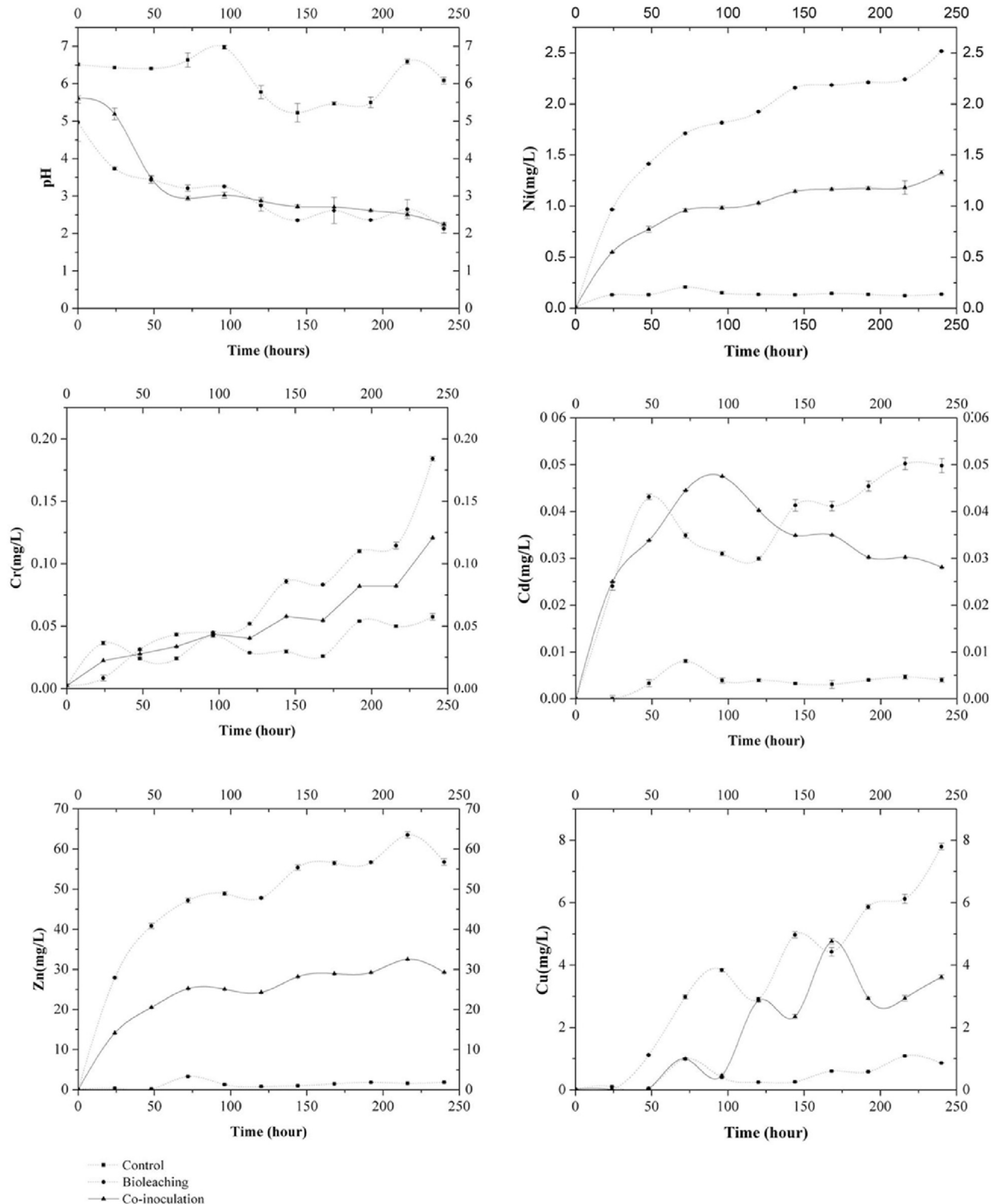

- Bioleaching

$\perp$ Co-inoculation

Fig. 2. Variation of acidity (pH) of the reactors (A) and concentration ( $\mathrm{mg} / \mathrm{L})$ of $\mathrm{Ni}(\mathrm{B}), \mathrm{Cr}(\mathrm{C}), \mathrm{Cd}(\mathrm{D}), \mathrm{Zn}(\mathrm{E})$ and $\mathrm{Cu}(\mathrm{F})$ in the liquid phase of the sludge over the $240 \mathrm{~h}$ period.

bioleaching efficiency in sewage sludge, with solubilization obtained from $82 \%$ for $\mathrm{Cu}$ and $92 \%$ for $\mathrm{Zn}$ in the co-inoculation assays, and $64 \%$ for $\mathrm{Cu}$ and $84 \%$ for $\mathrm{Zn}$ in the same range, $132 \mathrm{~h}$ in the assays containing only Acidithiobacillus.

The results obtained show that adding yeast promoted a delay that was not expected in the solubilization of the metals (Fig. 2A).
One possible explanation is that this species could be a bioaccumulator of metals, or also that its cell wall can act as a good adsorbent for these elements (Bishnoi and Garima, 2005), therefore more studies on the interaction between these elements and these microorganisms would be needed. Previous studies have demonstrated the possibility of using other genera of yeasts, such as 


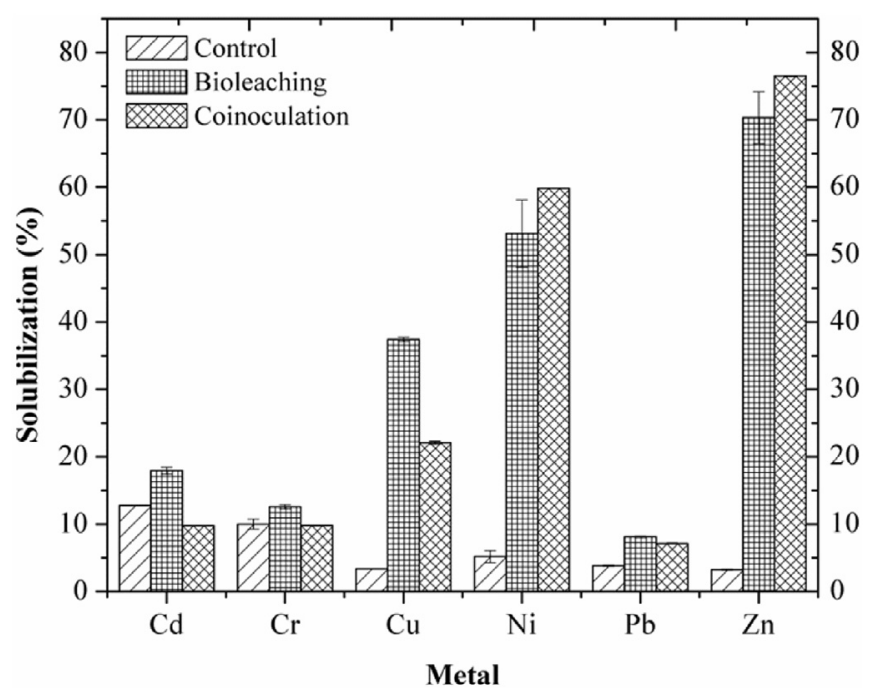

Fig. 3. Solubilization (\%) of potentially toxic metals from the solid phase of sewage sludge after different assays. Error bars are relative to two independent samplings.

Saccharomyces cerevisiae, as sorbent material capable of removing metal ions such as Cd (II) from river water (Biscaro et al., 2007; Menegário et al., 2010) and bioaccumulation of $\mathrm{Cu}(\mathrm{II})$ by Pichia guilliermondii (teleomorph Meyerozyma guilliermondii) (De Silóniz et al., 2002; Menegário et al., 2007), which may explain the decrease in the solubilization of this metal in the co-inoculation assays (Fig. 3).

It is important to note that the sorptive affinity of the metal depends on its properties, surface type and also experimental conditions (McLean and Bledsoe, 1992), therefore it is important that differences in the solubilization potential of metals of different treatments are compared for the same matrix, especially in the case of sewage sludge, which varies greatly in composition and physicochemical properties.

The correlation coefficient analyses between the metal solubility and $\mathrm{pH}$ (Table 2), the highest correlations between $\mathrm{pH}$ and solubilization of metals were observed for $\mathrm{Ni}$ and $\mathrm{Zn}$ metals in the bioleaching assay and for metals $\mathrm{Cd}, \mathrm{Ni}$ and $\mathrm{Zn}$ in the co-inoculation assay. These data show that, in general, although the bioleaching assay presented a greater solubilization of metals, in the coinoculation assay this solubilization seems to be more related to the decrease in the $\mathrm{pH}$ for a greater number of metals.

\subsection{Theoretical study of the solubility of metals at different $\mathrm{pH}$ values}

The indirect evaluation of the solubility of different metals ( $\mathrm{Cd}$, $\mathrm{Cr}, \mathrm{Cu}, \mathrm{Ni}, \mathrm{Pb}$ and $\mathrm{Zn}$ ) at the initial (7.4) and final (2.0) $\mathrm{pH}$ of the sewage sludge after the bioleaching tests was done using the Visual MINTEQ 3.1 software (Gustafsson, 2016) in order to predict the formation of precipitates that could interfere with analysing the

Table 2

Correlation coefficient and P value. Data obtained by Graph Pad Instat software for parametric ANOVA test with $95 \%$ confidence interval.

\begin{tabular}{llll}
\hline Metal & Control & Bioleaching & Co-inoculation \\
\hline $\mathrm{Cd}$ & $0.0356 ; \mathrm{p}=.9761$ & $-0.8941 ; \mathrm{p}=.0002$ & $-0.9630 ; \mathrm{p}<.0001$ \\
$\mathrm{Cr}$ & $0.2259 ; \mathrm{p}=.50-42$ & $-0.8248 ; \mathrm{p}=.0018$ & $-0.7720 ; \mathrm{p}=.0054$ \\
$\mathrm{Cu}$ & $0.1586 ; \mathrm{p}=.6414$ & $-0.8651 ; \mathrm{p}=.0006$ & $-0.7150 ; \mathrm{p}=.0134$ \\
$\mathrm{Ni}$ & $-0.3745 ; \mathrm{p}=.2563$ & $-0.9558 ; \mathrm{p}<.0001$ & $-0.9776 ; \mathrm{p}<.0001$ \\
$\mathrm{Zn}$ & $0.0131 ; \mathrm{p}=.9695$ & $-0.9453 ; \mathrm{p}<.0001$ & $-0.9853 ; \mathrm{p}<.0001$ \\
\hline
\end{tabular}

solubility of metals.

Based on the analyses, it was observed that all elements would be predominantly in the form of soluble species under the conditions analyzed, except for $\mathrm{Pb}$, since at $\mathrm{pH} 7.4$, approximately $13.5 \%$ of this element was present in the $\mathrm{PbSO}_{4}$ species and $1 \%$ as $\mathrm{Pb}$ $\left(\mathrm{SO}_{4}\right)_{2}^{2-}$, both insoluble. Similarly, at $\mathrm{pH} 2.0,23.6 \%$ of the total $\mathrm{Pb}$ would be in the form of $\mathrm{PbSO}_{4}$ and $1.4 \%$ in the form of $\mathrm{Pb}\left(\mathrm{SO}_{4}\right)_{2}^{2-}$. Thus, the results of the analyses carried out in the bioleaching experiments for this element may be underestimated due to the formation of precipitates.

According to Pathak et al. (2009), although sulfur was added in an elemental form as an energy source at the beginning of the tests, it is understood that there is no formation of sulphides throughout the treatments, since due to the oxidizing atmosphere, as well as the microbial metabolism, the tendency would be the formation of $\mathrm{H}_{2} \mathrm{SO}_{4}$.

\subsection{Potential of bioleached sewage sludge applied on farmland}

Key points to be verified for sewage use in agricultural land are: contain a low concentration of contaminants regarding metals, the maximum concentrations of metals allowed for this use and their cumulative effects (Tsutiya, 2015).

The sewage used seems to be a promising option on low income countries. Indeed, according to Nogueira et al. (2013), the use of sewage sludge as fertilizer to increase the concentration of nutrients in soils can also increase the concentration of many metals in the agricultural systems, however it poses no hazard to the environment, even in Brazilian soils, which can be quite different from temperate soils. Thus, the economic potential of using sewage sludge as a substitute for commercial fertilizers should be considered.

In the State of São Paulo, Brazil, the maximum permitted metal limits in biosolids were based on the maximum limits allowed in the United States and defined in Standard P4.230 (CETESB, 1999). Furthermore, its definition was based on risk analysis, whereas the definition of the European Community and Canadian standards, for example, used the concept of non-degradation of the soil and the environment (Tsutiya, 2015).

Table 3 shows a comparison between the maximum permissible concentrations of metals for agricultural use in different localities, the initial concentrations of metals in the anaerobic sewage sludge and the concentrations obtained in the solid phase of the sewage sludge after the bioleaching tests and co-inoculation. The product obtained after the bioleaching and co-inoculation tests reached the maximum permissible concentrations for $\mathrm{Zn}$ in the State of São Paulo/United States. In addition, it is within the limits for other metals according to the requirements of the European Community (Tsutiya, 2015).

\section{Table 3}

Comparison between the maximum permissible concentrations of metals in the biosolids for agricultural use in different localities, the initial concentrations of metals in the anaerobic sewage sludge and the concentrations obtained from the sewage sludge after the bioleaching and co-inoculation tests.

\begin{tabular}{lllllll}
\hline \multirow{2}{*}{ Local } & \multicolumn{7}{l}{ Maximum concentration allowed, $\mathrm{mg} / \mathrm{kg}$} \\
\cline { 2 - 7 } & $\mathrm{Cd}$ & $\mathrm{Cr}$ & $\mathrm{Cu}$ & $\mathrm{Ni}$ & $\mathrm{Pb}$ & $\mathrm{Zn}$ \\
\hline Bioleaching & 17.2 & 542.5 & 1378.6 & 166.9 & 414.6 & 2438.6 \\
Co-inoculation & 18.2 & 552.0 & 1714.2 & 140.3 & 421.6 & 2008.4 \\
Initial concentration & 20.7 & 619.9 & 2201.0 & 356.1 & 451.2 & 8216.8 \\
São Paulo & 85 & - & 4300 & 420 & 840 & 7500 \\
United States & 85 & - & 4300 & 420 & 840 & 7500 \\
European Community & 40 & - & 1750 & 400 & 1200 & 4000 \\
Canada & 20 & - & - & 180 & 500 & 1850 \\
\hline
\end{tabular}


It can be observed that the sewage sludge used in this study was at the beginning of the experiments within the limits of the maximum permitted concentrations in the State of São Paulo and in the United States, except for $\mathrm{Zn}$, where the maximum permissible concentration is $7500 \mathrm{mg} / \mathrm{kg}$ and the result obtained after the initial characterization of the material was $8216.8 \mathrm{mg} / \mathrm{kg}$. However, when countries with less lenient and more environmentally friendly laws are taken into account, such as the European Community and Canada, it is understood that all metals analyzed, with the exception of $\mathrm{Pb}$, would be above the maximum limits allowed.

\section{Conclusions}

After 10 days of incubation at $30^{\circ} \mathrm{C}$, besides a reduction of the nitrogen concentration by $20.1 \%$ and phosphorus by $7.6 \%$, the coinoculation of M. guilliermondii and Acidithiobacillus was able to solubilize $76.5 \%$ of $\mathrm{Zn}, 59.8 \%$ of $\mathrm{Ni}, 22.0 \%$ of $\mathrm{Cu}, 9.8 \%$ of $\mathrm{Cd}, 9.8 \% \mathrm{Cr}$ and $7.1 \%$ of $\mathrm{Pb}$. M. guilliermondii inoculation accelerated the solubilization of Cd, reducing the required time from 240 to $96 \mathrm{~h}$.

Since the co-inoculation assays presented lower solubilization for the other studied metals, it is possible to infer that the addition of the yeast strain promoted a delay in the solubilization of these metals, suggesting that the specie $M$. guilliermondii could be a bioaccumulator of metals, or also that its cell wall can act as an adsorbent for these elements. Therefore, more studies on the interaction between these elements and these microorganisms would be needed.

After the bioleaching and co-inoculation tests, the product obtained reached the maximum permissible concentrations for soil disposal for all the analyzed metals in the State of São Paulo and in the United States standards and also with requirements of the European Community. It is important to note that even if current methods cannot generate an end product that can be used as fertilizers, treating sewage sludge should not be neglected because its inadequate disposal is environmentally harmful. Furthermore, it should be considered that its application can improve the physical characteristics of the soil, although it does not influence its nutritional characteristics.

\section{Acknowledgements}

The authors would like to thank MSc Cláudia Watanabe and Dr. André Henrique Rosa for the help with the metal analysis and the Hydrometallurgy Laboratory from São Paulo State University (UNESP) "Júlio de Mesquita Filho" for the concession of the Aciditiobacillus strains. This work was funded by the National Council for Scientific and Technological Development (CNPq) (process number 442833/ 2014-8) and the Coordination for the Improvement of Higher Education Personnel (CAPES).

\section{References}

APHA/AWWA/WEF, 2012. Standard methods for the examination of water and wastewater. In: Standard Methods, twenty-second ed. American Public Health Association, Washington, DC, USA, ISBN 9780875532356.

Azizi, A.B., Lim, M.P.M., Noor, Z.M., Abdullah, N., 2013. Vermiremoval of heavy metal in sewage sludge by utilising Lumbricus rubellus. Ecotoxicol. Environ. Saf. 90, 13-20. https://doi.org/10.1016/j.ecoenv.2012.12.006.

Banat, I.M., Franzetti, A., Gandolfi, I., Bestetti, G., Martinotti, M.G., Fracchia, L., Smyth, T.J., Marchant, R., 2010. Microbial biosurfactants production, applications and future potential. Appl. Microbiol. Biotechnol. 87, 427-444. https:// doi.org/10.1007/s00253-010-2589-0.

Biscaro, P.A., Menegário, A.A., Tonello, P.S., Caldorin, R., 2007. Pré-concentração de cádmio com Saccharomyces cerevisiae e determinação em águas fluviais usando espectrometria de emissão óptica com plasma indutivamente acoplado. Quim. Nova 30, 323-326. https://doi.org/10.1590/S0100-40422007000200016.

Bishnoi, N.R., Garima, A., 2005. Fungus - an alternative for bioremediation of heavy metal containing wastewater: a review. J. Sci. Ind. Res. India 64, 93-100.

Blais, J.F., Tyagi, R.D., Auclair, J.C., 1993. Bioleaching of metals from sewage sludge: microorganisms and growth kinetics. Water Res. 27, 101-110. https://doi.org/ 10.1016/0043-1354(93)90200-2.

Camargo, F.P., Sérgio Tonello, P., Dos Santos, A.C.A., Duarte, I.C.S., 2016. Removal of toxic metals from sewage sludge through chemical, physical, and biological treatments-a review. Water. Air. Soil Pollut. 227, 433. https://doi.org/10.1007/ s11270-016-3141-3.

CETESB, C. de T. de S.A., 2004. Norma Técnica no L5.217. Thiobacillus: determinação do número mais provável pela técnica dos tubos múltiplos: método de ensaio.

CETESB, C. de T. de S.A., 1999. Norma P4.230: Aplicação de lodos de sistemas de tratamento biológico em áreas agrícolas - Critérios para projeto e operação.

Chen, S.Y., Lin, J.G., 2001. Bioleaching of heavy metals from sediment: significance of pH. Chemosphere 44, 1093-1102. https://doi.org/10.1016/S0045-6535(00) 00334-9.

De Silóniz, M.I., Balsalobre, L., Alba, C., Valderrama, M.J., Peinado, J.M., 2002. Feasibility of copper uptake by the yeast Pichia guilliermondii isolated from sewage sludge. Res. Microbiol. 153, 173-180. https://doi.org/10.1016/S09232508(02)01303-7.

Du, F., Freguia, S., Yuan, Z., Keller, J., Pikaar, I., 2015. Enhancing toxic metal removal from acidified sludge with nitrite addition. Environ. Sci. Technol. 49, 6257-6263. https://doi.org/10.1021/es504507m.

Fang, D., Zhang, R., Zhou, L., Li, J., 2011. A combination of bioleaching and bioprecipitation for deep removal of contaminating metals from dredged sediment. J. Hazard. Mater. 192, 226-233. https://doi.org/10.1016/ j.jhazmat.2011.05.008.

Fang, D., Zhou, L.X., 2007. Enhanced Cr bioleaching efficiency from tannery sludge with coinoculation of Acidithiobacillus thiooxidans TS6 and Brettanomyces B65 in an air-lift reactor. Chemosphere 69, 303-310. https://doi.org/10.1016/ j.chemosphere.2007.03.059.

Gustafsson, J.P., 2016. Visual MINTEQ 3.1. http://www2.lwr.kth.se/english/ outsoftware/vminteq/index.html. Stockholm, Sweden. 03. out. 2016.

Karwowska, E., Andrzejewska-Morzuch, D., Łebkowska, M., Tabernacka, A., Wojtkowska, M., Telepko, A., Konarzewska, A., 2014. Bioleaching of metals from printed circuit boards supported with surfactant-producing bacteria. J. Hazard. Mater. 264, 203-210. https://doi.org/10.1016/j.jhazmat.2013.11.018.

Kumar, R.N., Nagendran, R., 2007. Influence of initial pH on bioleaching of heavy metals from contaminated soil employing indigenous Acidithiobacillus thiooxidans. Chemosphere 66, 1775-1781. https://doi.org/10.1016/ j.chemosphere.2006.07.091.

Mao, X., Jiang, R., Xiao, W., Yu, J., 2015. Use of surfactants for the remediation of contaminated soils: a review. J. Hazard. Mater. 285, 419-435. https://doi.org/ 10.1016/j.jhazmat.2014.12.009.

McLean, J.E., Bledsoe, B.E., 1992. Behavior of Metals in Soils. Office of Research and Development, pp. 1-25. https://doi.org/10.1056/NEJMoa030660.

Menegário, A.A., Tonello, P.S., Biscaro, P.A., Brossi-Garcia, A.L., 2007. Determination of $\mathrm{Cd}(\mathrm{II})$ and $\mathrm{Cd}$-metallothioneins in biological extracts using baker's yeast and inductively coupled plasma optical emission spectrometry. Microchim. Acta 159, 247-254. https://doi.org/10.1007/s00604-007-0783-2.

Menegário, A.A., Tonello, P.S., Durrant, S.F., 2010. Use of Saccharomyces cerevisiae immobilized in agarose gel as a binding agent for diffusive gradients in thin films. Anal. Chim. Acta 683, 107-112. https://doi.org/10.1016/j.aca.2010.10.016.

Mulligan, C.N., Yong, R.N., Gibbs, B.F., 2001. Heavy metal removal from sediments by biosurfactants. J. Hazard. Mater. 85, 111-125. https://doi.org/10.1016/S03043894(01)00224-2.

Naresh Kumar, R., Nagendran, R., 2009. Fractionation behavior of heavy metals in soil during bioleaching with Acidithiobacillus thiooxidans. J. Hazard. Mater. 169, 1119-1126. https://doi.org/10.1016/j.jhazmat.2009.04.069.

Ngom, B., Liang, Y., Liu, Y., Yin, H., Liu, X., 2014. Use of an acidophilic yeast strain to enable the growth of leaching bacteria on solid media. Arch. Microbiol. 197, 339-346. https://doi.org/10.1007/s00203-014-1051-6.

Nogueira, T.A.R., Franco, A., He, Z., Braga, V.S., Firme, L.P., Abreu-Junior, C.H., 2013. Short-term usage of sewage sludge as organic fertilizer to sugarcane in a tropical soil bears little threat of heavy metal contamination. J. Environ. Manage. 114, 168-177. https://doi.org/10.1016/j.jenvman.2012.09.012.

Pathak, A., Dastidar, M.G., Sreekrishnan, T.R., 2009. Bioleaching of heavy metals from sewage sludge: a review. J. Environ. Manage. 90, 2343-2353. https:// doi.org/10.1016/j.jenvman.2008.11.005.

Pedroza, M.M., Vieira, G.E.G., Sousa, J.F.de, 2011. Chemical characteristics of sewage sludge produced in Brazil. Rev. AIDIS Ing. y Ciencias Ambient. Investig. Desarro. y práctica $4,35-47$.

Pinheiro, C.H.R., 2007. Zn, Ni, Cr, Cu, Fe e S em lodo de esgoto: comportamento químico, adsorção e proposta de tratamento. Universidade de São Paulo (USP). https://doi.org/10.11606/T.44.2008.tde-15052008-153050.

Polak, J., Sułkowski, W.W., Bartoszek, M., Papiez, W., 2005. Spectroscopic studies of the progress of humification processes in humic acid extracted from sewage sludge. J. Mol. Struct. 744-747, 983-989. https://doi.org/10.1016/ j.molstruc.2004.12.054.

Silverstein, R., Webster, F., 1981. Spectrometric Identification of Organic Compounds, fourth ed.

Tsutiya, M.T., 2015. Metais pesados: o principal fator limitante para o uso agrícola de biossólidos das estações de tratamento de esgotos. In: Engenharia Sanitária E Ambiental, pp. 753-761. Rio de Janeiro.

USEPA, 1996. Method 3050B - Acid Digestion of Sediments, Sludges, and Soils, p. 12. https://doi.org/10.1117/12.528651.

Wen, Y.M., Cheng, Y., Tang, C., Chen, Z.L., 2013. Bioleaching of heavy metals from sewage sludge using indigenous iron-oxidizing microorganisms. J. Soils 
Sediments 13, 166-175. https://doi.org/10.1007/s11368-012-0580-3.

Wong, J.W.C., Xiang, L., Gu, X.Y., Zhou, L.X., 2004. Bioleaching of heavy metals from anaerobically digested sewage sludge using FeS2 as an energy source. Chemosphere 55, 101-107. https://doi.org/10.1016/j.chemosphere.2003.11.022.

Zhang, W., Yang, L., Wang, A.H., Wang, C.W., Zhou, J., 2014. Advance of sludge producing, hazards and disposal methods. Adv. Mater. Res. 1033-1034, 369-377. https://doi.org/10.4028/www.scientific.net/AMR.1033-1034.369.

Zheng, G., Zhou, L., 2011. Supplementation of inorganic phosphate enhancing the removal efficiency of tannery sludge-borne $\mathrm{Cr}$ through bioleaching. Water Res.
45, 5295-5301. https://doi.org/10.1016/j.watres.2011.07.031.

Zhou, J., Zheng, G., Wong, J.W.C., Zhou, L, 2013a. Degradation of inhibitory substances in sludge by Galactomyces sp. Z3 and the role of its extracellular polymeric substances in improving bioleaching. Bioresour. Technol. 132, 217-223. https://doi.org/10.1016/j.biortech.2012.12.179.

Zhou, J., Zheng, G., Zhou, L., Liu, F., Zheng, C., Cui, C., 2013b. The role of heterotrophic microorganism Galactomyces sp. Z3 in improving pig slurry bioleaching. Environ. Technol. 34, 35-43. https://doi.org/10.1080/09593330.2012.679699. 